\title{
The influence of some rooting biostimulators on Chrysanthemum cultivars via stem cuttings
}

\author{
M. Cantor1, T. Buru1, Zs. Szekely-Varga², and E. Buta ${ }^{1 *}$ \\ 1University of Agricultural Sciences and Veterinary Medicine Cluj-Napoca, \\ Department of Horticulture and Landscaping, Cluj-Napoca, Romania. \\ 2Sapientia Hungarian University of Transylvania, Department of Horticulture, \\ Faculty of Technical and Human Sciences, Targu Mures/Corunca, Romania. \\ *Corresponding author email: erzsebet.buta@usamvcluj.ro
}

\begin{abstract}
Chrysanthemum is one of the top cultivated flowers, the undisputed queen of gardens in the autumn season. Due to its exceptional decorative qualities having a special range of shapes and colors, storage resistance, suitability in different cultivation systems and the possibility of cultivation all over the year chrysanthemum is one of the most loved and appreciated flowers. It is one of the major crops worldwide and it is cultivated as cut flowers and potted plants, depending on market demand. In Romania, nowadays, the cultivated areas with Chrysanthemum are developing quickly through potted cultures which have gained a significant increase. Also, due to the progress made in the selection of chrysanthemums, many cultivars have been introduced in the recent plant assortment. The present study was carried out to evaluate the influence of three rooting biostimulators on five potted chrysanthemums cultivars to determine the most efficient way to obtain a significant result for roots and aerial part's growth and development. The greatest effects of rooting were obtained with Radistim 1 biostimulator. In which case was determined an increase of rooting percentage, number of roots, the height of plants, number of leaves and number of branches.
\end{abstract}

Keywords: Chrysanthemum, cuttings, rooting, potted plants, propagation, cultivars.

\section{INTRODUCTION}

Chrysanthemum in many countries, including the United States, China and Japan, is considered the number one crop (Cockshull, 2019). Chrysanthemum flowers are mainly used for cut flower, loose flowers for garland making, general decoration, hair adornments and religious functions (Kumar, 2015). However, nowadays, can be found in landscape architecture arrangements or private gardens (Vidrașcu and Teodorescu, 1993; Anderson, 2007), but also in flower shops and floral design using the most cultivated species for the production of cut flowers, both in a greenhouse and in the field is Chrysanthemum $\times$ hortorum Hort. (Cantor, 2016; Su et al., 2019). Due to the diversity of shapes and sizes of the inflorescence, the multitude of colors, its suitability for modern homes, make this flower species to be highly appreciated by the general public, and can be grown sustainably while simultaneously providing an economic benefit for growers.

The dwarf and compact growing types (spray chrysanthemums) are cultivated as potted plants for decorating indoors and outdoors whereas the erect and tall growing types (standard chrysanthemums) are grown as cut flowers for bouquets and vase decoration 
(Singh and Chettri, 2013). Chrysanthemums are used either as cut flowers or grown in pots and the success in the cultivation of this plant is principally due to the great diversity of cultivars (Jamal Uddin et al., 2015). Generally, due to the richness of shapes and colors, chrysanthemums can be combined with each other, but can also be combined with other flowering species. As a cut or in potted flowers, chrysanthemums can be used for numerous occasions all year round (Buta et al., 2013).

Chrysanthemums are mostly propagated by the vegetative method by cuttings (Toma, 2009). There is, however, great variability in the ability to form adventitious roots and regenerate new individuals by cuttings. Some cultivars are relatively easy to propagate by cuttings, however some species have a low capacity to root (Cojocariu and Tănase, 2019). The cuttings are harvested from mother plants especially cultivated and set up for this purpose. They are harvested from the shoots that have grown at the base of the bushes, when they have reached a length of 8-10 cm and 4-5 leaves, after which they are shaped by removing the leaves from the base on 3-4 cm long and cut 1/3 of the top of the leaves to reduce transpiration (Vidrașcu and Teodorescu, 1993).

Rooting of cuttings is done at a temperature of $20-22^{\circ} \mathrm{C}$, and relative humidity of $80-90 \%$. Rooting time is between 23-25 days, which could be season or plant depending.

Treatment with biostimulators is considered to have an important influence in increasing the rooting process and the percentage of rooted cuttings. Hormone treatment is one of the most important factors due to enhance the initiation of the root primordia and growth through cell multiplication (Fogasa and Fett-Neto, 2005). Hormones support the mobilization of sugars and nutrients by the hydrolysis of starch to the base of the cuttings (Das et al., 1997). The plant growth regulators like auxin are used to increase the percentage of rooting in stem cuttings for quick root initiation and to increase the number of roots per cutting (Garande et al., 2002). A new method of propagation of chrysanthemum through leaf cuttings complementary to the conventional method of shoot tip propagation was developed under in vivo conditions by Singh and Chettri, (2013), leaf cuttings were treated with a combination of plant growth regulators (IBA and Kinetin). This propagation technique is particularly useful when propagating material is scarce as from a small quantity of initial propagating material, a large number of plants can be produced.

The present study presents the effect of some growth regulators on the rooting of mum cuttings and their influence on the morphological and biometrical characteristics of obtained plants.

\section{MATERIALS AND METHODS}

The experiment was carried out at the University of Agricultural Sciences and Veterinary Medicine, at the didactic greenhouse of the Floriculture, during the season, 2019-2020.

Five cultivars of potted Chrysanthemum plants were used as mother plants: 'Avalon cream', 'Avalon orange', 'Avalon purple', 'Ditto pink', 'Ditto dark pink' (Figure 1).

From each of the five cultivars, terminal (top) stem cuttings were taken from healthy mother plants, at the end of February. The cuttings were prepared as $6-8 \mathrm{~cm}$ cuttings, the first pairs of leaves were suppressed and only 3-4 leaves were left on the top. The rooting biostimulators used were: Radistim 1 and Razormin. The treated cuttings were planted in a substrate consisting of peat and perlite 1:1 ratio.

The studied factors were: Factor A: the chrysanthemum cultivar, with five graduations: $\mathrm{a}_{1}-$ 'Avalon cream'; $a_{2}$ - 'Avalon purple'; $a_{3}$ - 'Avalon orange'; $a_{4}$ - 'Ditto pink' and $a_{5}$ - 'Ditto dark pink' and Factor B: the type of rooting biostimulator with three graduations: $b_{1}-$ Untreated (Control); $b_{2}$ - Radistim 1; $b_{3}-$ Razormin. 
Through the combination of factors and their graduations, 15 experimental variants resulted, which were placed in randomized blocks, in 3 replicates each. Control was the untreated variant. There were 10 cuttings per treatment for each cultivar, a total of 30 cuttings/cultivar with a total of 450 cuttings.

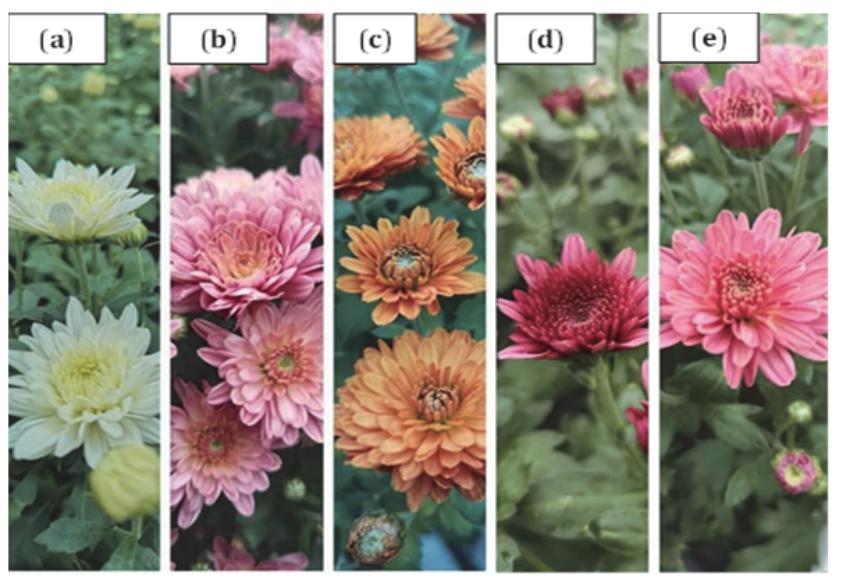

Figure 1. Chrysanthemum biological materials: 'Avalon cream' (a), 'Avalon purple' (b), 'Avalon orange'(c), 'Ditto pink' (d), 'Ditto dark pink' (e)

After 25 days observations were made on the percentage of rooting and after 8 weeks days biometric measurements were taken and the cuttings were planted in pots. The observations and determinations were made consisting measurements of the dimension and number of roots/cutting, length of roots and plants were recorded - height of cuttings, number of branches/plants, number of leaves/per plant, number of roots per cutting.

The data were interpreted statistically by calculating the average of experience, and the differences between the variants were established by analysing the variance and using the Duncan test (Ardelean et al., 2005).

\section{RESULTS AND DISCUSSIONS}

It can observe that the average number of cuttings rooted was 26.27 out of a total of 30 , and the variability depending on the variation between 21 (untreated cuttings) and 30 (cuttings treated with Radistim 1) (Table 1). The rooting percentage for each experimental variant was between $66.66 \%$ ('Avalon orange' - untreated) and $100.00 \%$ for 'Avalon cream' and 'Avalon purple' treated with Radistim-1. All five cultivars studied in the experiment treated with Radistim 1 had over 93.33\% rooting percentage. In a study, Cojocariu and Tănase (2019), reported that the rooting capacity of chrysanthemum cuttings could be also influenced by substrate. Rotting could be influenced by the stem type, from basal shoots or the stem tip of the vegetative growth period, although a higher yield was observed at cuttings and shoots grown at base (Johti et al., 1987).

In the current study, it was analysed the combination of A factor (cultivar) and B factor (treatment) on the high of rooted cutting, number of shoots, number of leaves, number of roots and interaction between these traits. 'Ditto dark pink' obtained the highest values in terms of rooted cutting height $(12.50 \mathrm{~cm})$ with significant superior differences compared with other studied cultivars. No significant differences were determined between cultivars 'Avalon orange' $(9.50 \mathrm{~cm})$ and 'Ditto dark pink' $(12.50 \mathrm{~cm})$ regarding the height of the rooted cuttings (Table 2). 
Table 1. Results obtained at the cuttings rooting

\begin{tabular}{|c|c|c|c|c|c|}
\hline $\begin{array}{l}\text { No. } \\
\text { Var. }\end{array}$ & Cultivar & Treatments & $\begin{array}{l}\text { Number of } \\
\text { cuttings }\end{array}$ & $\begin{array}{l}\text { Number of } \\
\text { rooted cuttings }\end{array}$ & $\begin{array}{c}\text { Rooting } \\
\text { percentage } \\
(\%)\end{array}$ \\
\hline \multirow{3}{*}{1} & \multirow{3}{*}{ 'Avalon cream' } & Untreated & 30 & 24 & 80.00 \\
\hline & & Radistim-1 & 30 & 30 & 100.00 \\
\hline & & Razormin & 30 & 29 & 99.66 \\
\hline \multirow{3}{*}{2} & \multirow{3}{*}{ 'Avalon purple' } & Untreated & 30 & 25 & 83.33 \\
\hline & & Radistim-1 & 30 & 30 & 100.00 \\
\hline & & Razormin & 30 & 29 & 99.66 \\
\hline \multirow{3}{*}{3} & \multirow{3}{*}{ 'Avalon orange' } & Untreated & 30 & 20 & 66.66 \\
\hline & & Radistim-1 & 30 & 29 & 99.66 \\
\hline & & Razormin & 30 & 27 & 90.00 \\
\hline \multirow{3}{*}{4} & \multirow{3}{*}{ 'Ditto pink' } & Untreated & 30 & 22 & 73.33 \\
\hline & & Radistim-1 & 30 & 28 & 93.33 \\
\hline & & Razormin & 30 & 26 & 86.66 \\
\hline \multirow{3}{*}{5} & \multirow{3}{*}{ 'Ditto dark pink' } & Untreated & 30 & 21 & 70.00 \\
\hline & & Radistim-1 & 30 & 29 & 99.66 \\
\hline & & Razormin & 30 & 25 & 76.67 \\
\hline \multicolumn{4}{|c|}{ Average experience (Control) } & 26.27 & 87.57 \\
\hline
\end{tabular}

Table 2. Influence of cultivar on the height of rooted cuttings

\begin{tabular}{|c|c|c|c|}
\hline No. var. & Cultivar & $\begin{array}{c}\text { Height of rooted } \\
\text { cuttings }(\mathrm{cm})\end{array}$ & $\begin{array}{c}\text { Significance of } \\
\text { difference* }\end{array}$ \\
\hline 1 & 'Avalon cream' & 10.50 & $\mathrm{AB}$ \\
\hline 2 & 'Avalon purple' & 11.50 & $\mathrm{AB}$ \\
\hline 3 & 'Avalon orange' & 9.50 & $\mathrm{~A}$ \\
\hline 4 & 'Ditto pink' & 11.50 & $\mathrm{AB}$ \\
\hline 5 & 'Ditto dark pink' & 12.50 & $\mathrm{~B}$ \\
\hline
\end{tabular}

*Notes: Letters represent the statistically significant difference at $p<0.05$ (Duncan test)

The results presented in Table 3 demonstrate the influence of the treatment on the height of the rooted cuttings, highlighting the importance of Radistim 1 hormonal treatment. Cutting treated with this substance achieved an average height of $12.9 \mathrm{~cm}$.

Table 3. Influence of treatment on the height of rooted cuttings

\begin{tabular}{|c|c|c|c|}
\hline Nr. var. & $\begin{array}{c}\text { Biostimulator } \\
\text { (treatment) }\end{array}$ & $\begin{array}{c}\text { Height of rooted } \\
\text { cuttings }(\mathrm{cm})\end{array}$ & $\begin{array}{c}\text { Significance of } \\
\text { differences* }\end{array}$ \\
\hline 1 & Untreated & 7.4 & A \\
\hline 2 & Radistim-1 & 12.9 & B \\
\hline 3 & Razormin & 9.8 & AB \\
\hline
\end{tabular}

*Notes: Letters represent the statistically significant difference at $p<0.05$ (Duncan test)

At the first four experimental variants the interaction between cultivar and treatment does not influence the height of rooted cutting. In the same way, in the case of treatment with Razormin the results are almost similar except for 'Avalon purple' cultivar. However, at $\mathrm{V}_{6}$, $\mathrm{V}_{8}, \mathrm{~V}_{9}, \mathrm{v}_{10}$ interaction between cultivar and hormonal treatment with Radistim 1 has an important influence on the height of rotted cuttings. Cultivars as 'Avalon cream', 'Avalon purple', 'Avalon orange', 'Ditto pink' and 'Ditto dark pink' present significant differences comparing with 'Avalon purple' (Figure 2). 


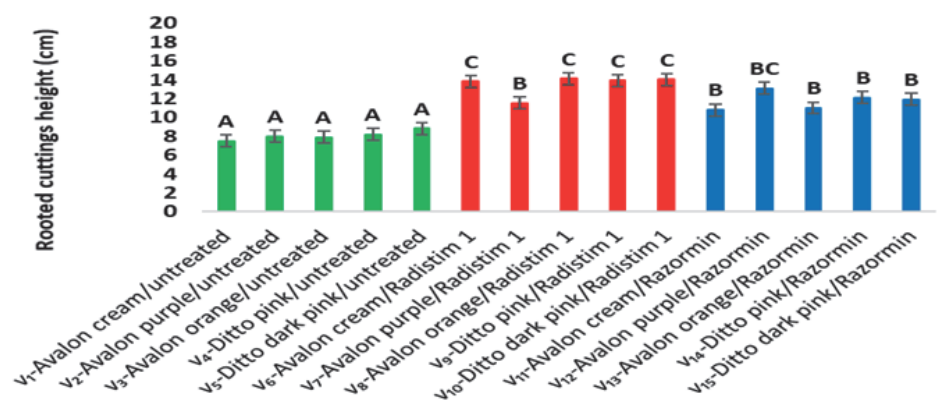

Figure 2. Influence of cultivar $\times$ treatment interaction on height of rooted cuttings. Bars represent standard errors. Letters represent the statistically significant difference at $p<0.05$ (Duncan test)

As it is presented in Table 4, the cultivar (factor A) has no influence on rotted cuttings branches; no significant differences were reported. Analysing Table 5, results from the second experimental factor (B) - hormonal treatment does not influence rotted cuttings branches, in the same way as the first factor (A).

Table 4. Influence of factor cultivar on the number of branches

\begin{tabular}{|c|c|c|c|}
\hline No. var. & Cultivar & Number of branches & Significance of differences* \\
\hline 1 & 'Avalon cream' & 2.10 & A \\
\hline 2 & 'Avalon purple' & 1.95 & A \\
\hline 3 & 'Avalon orange' & 1.85 & A \\
\hline 4 & 'Ditto pink' & 1.95 & A \\
\hline 5 & 'Ditto dark pink' & 2.25 & A \\
\hline
\end{tabular}

*Notes: Letters represent the statistically significant difference at $p<0.05$ (Duncan test)

Table 5. The influence of the treatment on the number of branches

\begin{tabular}{|c|c|c|c|}
\hline No. var. & Treatment & Number of branches & Significance of differences* \\
\hline 1 & Untreated & 1.65 & $\mathrm{~A}$ \\
\hline 2 & Radistim-1 & 2.15 & $\mathrm{~A}$ \\
\hline 3 & Razormin & 1.98 & $\mathrm{~A}$ \\
\hline
\end{tabular}

*Notes: Letters represent the statistically significant difference at $p<0.05$ (Duncan test)

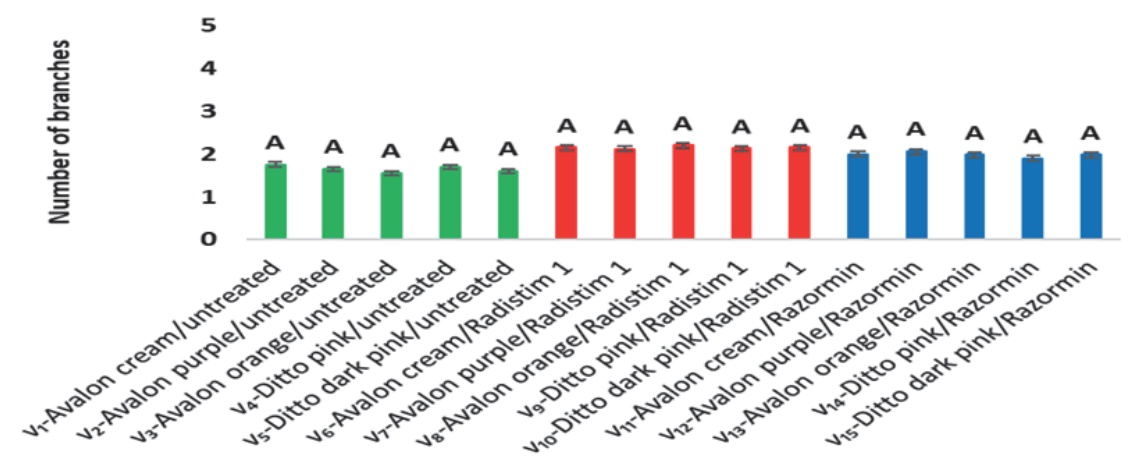

Figure 3. The influence of cultivar $\times$ treatment interaction on the number of branches. Bars represent standard errors. Letters represent the statistically significant difference at $p<0.05$ (Duncan test)

Regarding the influence of the interaction of cultivar and biostimulator and as the results shown in Figure 3 no significant differences were obtained, described variants forming a homogeneous group symbolized by the letter $\mathrm{A}$. 
Table 6. The influence of cultivar on the number of leaves of the plant

\begin{tabular}{|c|c|c|c|}
\hline No. var. & Cultivar & Number of leaves & $\begin{array}{c}\text { Significance of } \\
\text { differences* }\end{array}$ \\
\hline 1 & 'Avalon cream' & 8.50 & BC \\
\hline 2 & 'Avalon purple' & 7.30 & AB \\
\hline 3 & 'Avalon orange' & 6.70 & $\mathrm{~A}$ \\
\hline 4 & 'Ditto pink' & 9.00 & $\mathrm{C}$ \\
\hline 5 & 'Ditto dark pink' & 9.80 & $\mathrm{C}$ \\
\hline
\end{tabular}

*Notes: Letters represent the statistically significant difference at $p<0.05$ (Duncan test)

The highest average value of the number of leaves formed was recorded for cultivar 'Ditto dark pink' (9.80 as average) and the lowest value was for cultivar 'Avalon orange', an average of 6.70 leaves. Data presented in Table 6 demonstrate that from the five studied cultivars 'Ditto pink' (9.00) and 'Ditto dark pink' (9.80) achieved a higher number of leaves than the other studied cultivars.

Similar results were obtained by Cojocariu and Tănase (2019) at Chrysanthemum indicum 'Carmina', the greatest number of leaves formed was determined for TSF (top stem fragment) cuttings in peat substrate 100\% - 9.12 leaves as average, and the lowest value was for perlite (average 7 leaves).

It was determined the significant influence of hormonal treatment on the number of leaves, with major impact of both biostimulators Radistim 1 (9.40 leaves), followed by Razormin (8.20 leaves), while the number of leaves in case of untreated cuttings was only 6.25 (Table 7).

Table 7. The influence of treatment on the number of leaves of the plant

\begin{tabular}{|c|c|c|c|}
\hline No. var. & $\begin{array}{c}\text { Variant } \\
\text { (treatment) }\end{array}$ & Number of leaves & $\begin{array}{c}\text { Significance of } \\
\text { differences* }\end{array}$ \\
\hline 1 & Untreated & 6.25 & $\mathrm{~A}$ \\
\hline 2 & Radistim-1 & 9.40 & $\mathrm{~B}$ \\
\hline 3 & Razormin & 8.20 & $\mathrm{AB}$ \\
\hline
\end{tabular}

*Notes: Letters represent the statistically significant difference at $p<0.05$ (Duncan test)

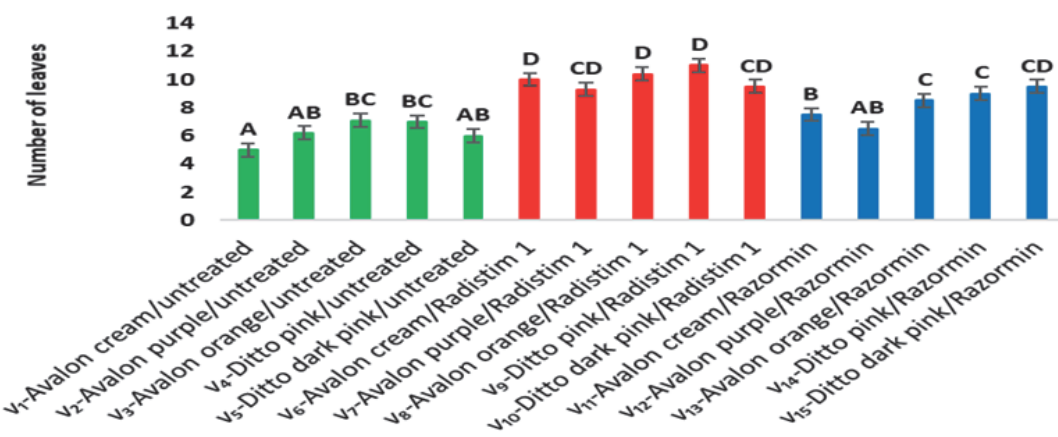

Figure 4. The influence of cultivar $\times$ treatment interaction on the number of leaves of the plant. Bars represent standard errors. Letters represent the statistically significant difference at $p<0.05$ (Duncan test)

Cultivar 'Ditto pink' presented the highest number of roots (11.50). Differences comparing with cultivars $V_{1}, V_{2}, V_{3}$ and $V_{5}$ were statistically significant (Table 8). 
Table 8. The influence of cultivar on the number of roots

\begin{tabular}{|c|c|c|c|}
\hline No. var. & Cultivar & Number of roots & $\begin{array}{c}\text { Significance of } \\
\text { differences* }\end{array}$ \\
\hline 1 & 'Avalon cream' & 8.83 & $\mathrm{~A}$ \\
\hline 2 & 'Avalon purple' & 9.50 & $\mathrm{~A}$ \\
\hline 3 & 'Avalon orange' & 9.40 & $\mathrm{~A}$ \\
\hline 4 & 'Ditto pink' & 11.50 & $\mathrm{~B}$ \\
\hline 5 & 'Ditto dark pink' & 9.70 & $\mathrm{~A}$ \\
\hline
\end{tabular}

*Notes: Letters represent the statistically significant difference at $p<0.05$ (Duncan test)

Treatment with Radistim 1 presents significant differences in the case of the number of roots (11.50) comparing with the control variant (Table 9).

Table 9. The influence of treatment on the number of roots

\begin{tabular}{|c|c|c|c|}
\hline No. var. & $\begin{array}{c}\text { Variant } \\
\text { (treatment) }\end{array}$ & Number of roots & $\begin{array}{c}\text { Significance of } \\
\text { differences* }\end{array}$ \\
\hline 1 & Untreated & 8.60 & $\mathrm{~A}$ \\
\hline 2 & Radistim-1 & 11.50 & $\mathrm{C}$ \\
\hline 3 & Razormin & 10.30 & $\mathrm{AB}$ \\
\hline
\end{tabular}

*Notes: Letters represent the statistically significant difference at $p<0.05$ (Duncan test)

Regarding the number of roots in the interaction of cultivar and rooting treatment with biostimulators, variants $\mathrm{v}_{6}, \mathrm{v}_{7}, \mathrm{v}_{9}$ and $\mathrm{v}_{10}$, treated with Radistim 1 obtained significant differences compared to the untreated variants followed by the variants treated with Razormin (Figure 5). The best results at the cultivar interaction with Radistim 1 treatment are reported at 'Avalon cream' and 'Avalon purple', which registered over 15 roots/rooted cuttings.

Similar results were obtained by Petter, (1992). The literature indicates a correlation between cultivar and rooting success of the cuttings, but with the use of IBA in different concentrations, the results were obtained for Chrysanthemum cv. Crimson Robe, cv. Polario, cv. Escort, cv. Sterling and cv. Luysona at $50 \mathrm{ppm}$ IBA, by spraying or immersing in root stimulator, thus obtaining a more compact root system.

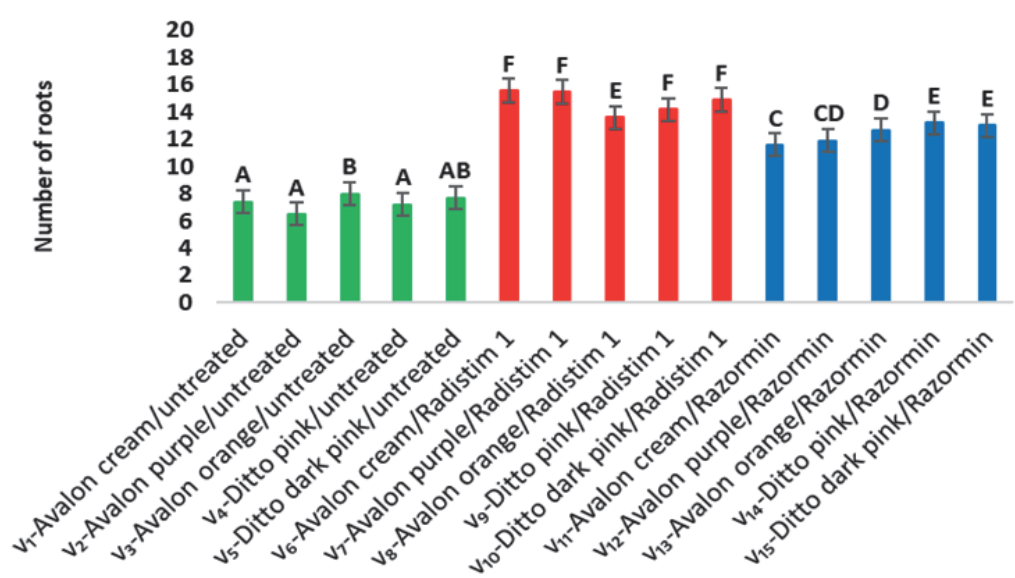

Figure 5. The influence of cultivar $\times$ treatment interaction on the number of roots. Bars represent standard errors. Letters represent the statistically significant difference at $p<0.05$ (Duncan test) 


\section{CONCLUSIONS}

Propagation by cuttings using different rooting biostimulators is a reliable technology that is applied for commercial purposes because it allows the large-scale production of a wide range of species especially Chrysanthemum. Treatment of cuttings is a crucial step in the adventitious root formation of chrysanthemum because it is a major exogenous factor affecting root formation and development of cuttings.

Radistim 1 obtained better results in the rooting of chrysanthemum cuttings and showed significance in the vegetative growth of cuttings. The rooting percentage was over $98.53 \%$ for Radistim 1 at all studied cultivars followed by the Razormin with $90.53 \%$, while the untreated cuttings rooted only in a percentage of $74.66 \%$.

Based on the observations it can be concluded that rooting of the cuttings at Chrysanthemum is cultivar and biostimulator dependent. Our study could be useful for growers and flower companies to select the greatest and treatment for cultivation.

\section{REFERENCES}

1. Anderson, N.O. (2007). Chrysanthemum. In Flower breeding and genetics Springer, Dordrecht, 389-437.

2. Ardelean, M., Sestras, R. and Cordea M. (2005). Tehnica experimentală horticolă, Editura AcademicPres, ClujNapoca, 61-67.

3. Buta, E., Cantor, M., Buta, M. and Horț, D. (2013). Multiplication and shaping of Chrysanthemum cultivars cultivated in pots, Journal of Horticulture, Forestry and Biotechnology, 17(1), 99-103.

4. Cantor M. (2016). Floricultură specială, Ed AcademicPres, Cluj-Napoca, 124-127.

5. Cockshull, K.E. (2019). Chrysanthemum morifolium. In CRC handbook of flowering 238-257). CRC Press.

6. Cojocariu, A. and Tănase, C. (2019). Development and testing a new technology for production of chrysanthemums planting material (Chrysanthemum sl). Journal of Plant Development, 26, 93-107.

7. Das, P., Basak, U. and Das, A. (1997). Metabolic changes during rooting in pre-girdled stem cuttings and air layers of Heritiera. Botanical Bulletin of Academia Sinica, 38, 91-95.

8. Fogasa, C.M. and Fett-Neto, A.G. (2005). Role of auxin and its modulators in the adventitious rooting of Eucalyptus species differing in recalcitrance. Plant Growth Regulation, 4(1),1-10.

9. Garande, V.K.; Gawade, M.H.; Sapkal, K.T. and Gurav, S.B. (2002). Effect of IBA and number of internodes on rooting of stem cuttings of grapes rootstocks. Agriculture Science Direct, 22(3), 176-178.

10. Jothi, L.J., Nanjan, K., Chezhiyan, N. and Khader, M. A. (1987). Influence of propagules, medium and season on rooting of chrysanthemum cuttings. South Indian Horticulture, 35(3), 220-225.

11. Jamal Uddina A.F.M., Taufiquea T., Onaa, A. F., Shahrina, S. and H. Mehraj, H. (2015). Growth and flowering performance evaluation of thirty- two chrysanthemum cultivars. J. Biosci. Agric. Res. 04(01): 40-51.

12. Kumar, M. (2015). Impact of different sources of nutrients on growth and flowering in Chrysanthemum (Chrysanthemum morifolium Ramat.) Cv Yellow Gold, Journal of Plant Development Sciences, 7(1), 49-53.

13. Petter, S. (1992). More marketable plants in a shorter time. Gartenbau Magazin, 1(6), 68-70.

14. Singh, P. and Chettri, R. (2013). A new propagation method for rapid multiplication of chrysanthemum under in vivo conditions. International Journal of Conservation Science, Vol. 4 Issue 1, 95-100.

15. Su, J., Jiang, J., Zhang, F., Liu, Y., Ding, L., Chen, S. and Chen, F. (2019). Current achievements and future prospects in the genetic breeding of Chrysanthemum: a review. Horticulture Research, 6(1), 1-19.

16. Toma F. (2009). Floricultură și artă florală. Specii utilizate pentru producerea florilor tăiate, Ed. INVELMultimedia București, Vol.2, 29-30, 42-45.

17. Vidrașcu, P. and Teodorescu, G. (1993). Crizantema. Ed. Ceres București, 99. 